\title{
THE IMPACT OF FINANCIAL PERFORMANCE AND MACROECONOMICS ON THE STOCK RETURNS OF THE COMPANY IN CONSTRUCTION AND BUILDING SUBSECTORS
}

\author{
Kharisma Yudha*, Hartoyo Sri, Maulana Tb. Nur Ahmad \\ School of Business, IPB University, Indonesia \\ *E-mail: yudhakharisma0404@gmail.com
}

\begin{abstract}
The research focuses on a phenomenon of decreased stock prices for construction and building subsectors in the Indonesian Stock Exchange during the development of infrastructures by the government. It analyzes the impact of financial performances and macroeconomics towards the stock returns of construction and building subsectors in the Indonesian Stock Exchange, using the data panel regression. The variables of Debt to Equity Ratio (DER), Return On Equity (ROE), Price Book Value (PBV), inflation rates and government policies affect the stock returns of construction and building subsector significantly, while the Current Ratio (CR), Total Asset Turn Over (TAT), and Price to Earning Ratio (PER) do not have significants impacts towards the stock returns.
\end{abstract}

\section{KEY WORDS}

Construction, building, financial performance, macroeconomics, stock returns.

The availability of infrastructures is very important to increase the process of national development and is one of the main factors for economic growth (Kodoatie, 2005). Upon realizing this, the government of Indonesia publishes the Presidential Regulation number 75 of 2014, about the availability of infrastructures, to increase the availability of prioritized infrastructures and forms the Committee to Increase the Availability of Prioritized Infrastructures (KPPIP). The government also allocates the National Budget (APBN) for infrastructures, with the largest amount of increase during the period of 2014 to 2017 compared previous period with growth $157 \%$.

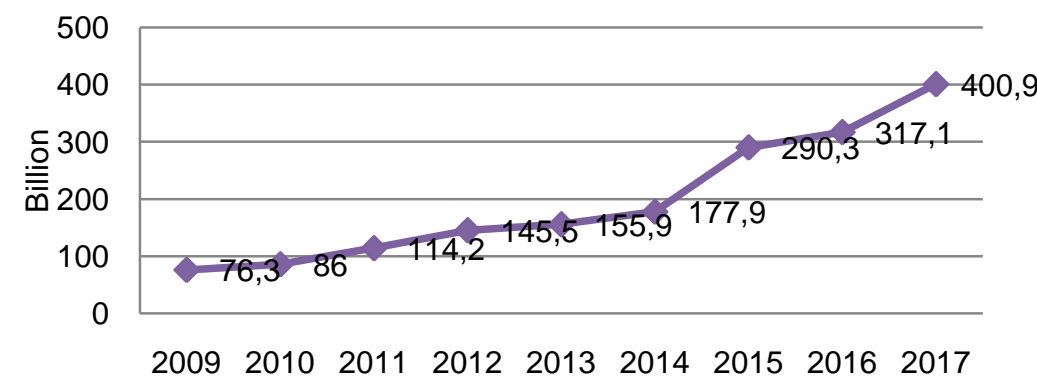

Figure 1 - The Allocation of the National Budget for Infrastructures (Source: Ministry of Finance)

The subsectors for the availability of infrastructures are constructions and buildings. The data from BPS shows that for the last three years, the construction sector has contributed consistently and became the second largest sector in Indonesia. This is the main reason to analyze financial performances of the stock returns of the company in construction and building subsectors. The analysis will be represented throught the financial ratios, as it is considered accurate to portray the operations or other fundemental aspects of the company towards the extensive business competition. Hamton (1990) stated that the aspects of finacial performances could be measured through various time periods, samples, and test variables, which could be beneficial for future researches, both repetition and development. The fluctuative movement of the stock returns is also influenced by fundamental factors, 
based on the ratios of companies accounts. In addition, the macroeconomic factors, such as inflations and exchange rates towards US dollars, can also influence the stock returns.

The closing stock price of constructions and buildings is fluctuating and often decreasing, which is not in line with the expectation of a positive impact from the policy in increasing amount of the national budget for infrastructure. impact to the increasing amount of the National Budget for infrastructures. This requires an analysis of a company's financial performances, represented by its internal (financial performance ratios) and external sectors (inflation and exchange) of the construction and building subsectors, and the influence of the factors (internal and external) on the stock return of construction and building subsector .

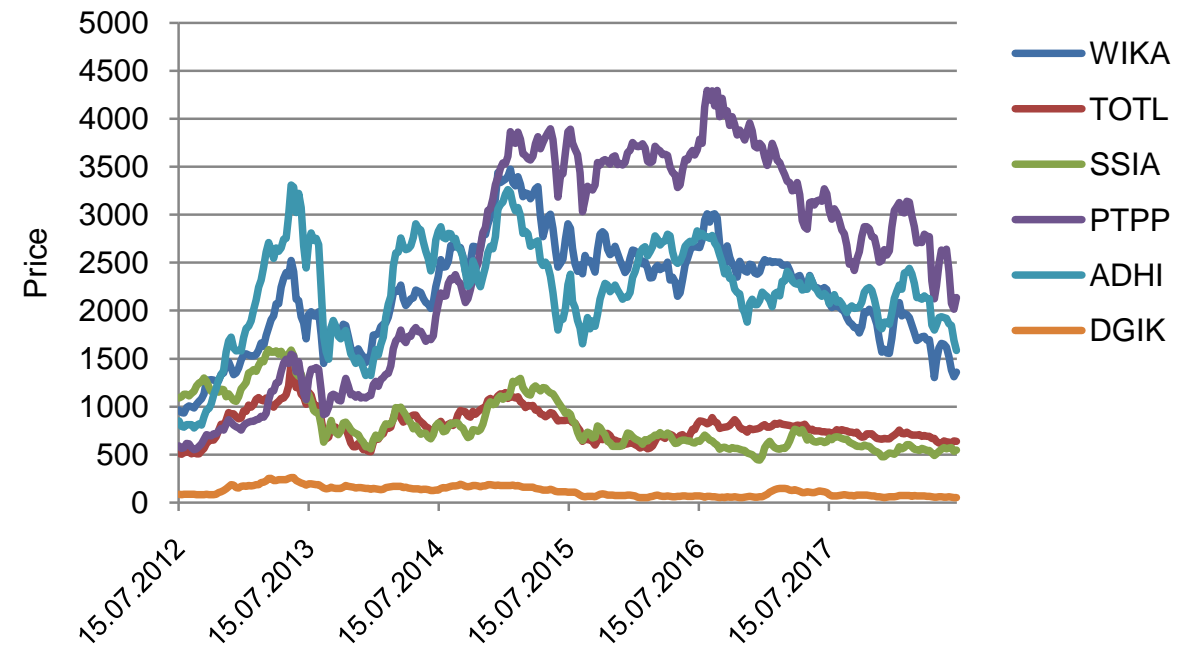

Figure 2 - Stock Price of construction and building subsectors

Based on the explanations above, the research question for this study is: "What is the influence of the financial performances and macroeconomics towards the stock returns of the construction and building subsectors in the Indonesian Stock Exchange from 2011 to 2017?" The research aims to analyse the influence of the financial performances and macroeconomics towards the stock returns of the construction and building subsectors in the Indonesian Stock Exchange from 2011 to 2017.

\section{LITERATURE REVIEW}

In order to increase the financial performances, a company has to apply a coherent strategical approach (Weinzimmer et al. 2012). As a measurement for a company's financial and performance conditions, a financial analyst acquires a standard of measurement. One of which is the financial ratio, which is also one of the important steps of analysis (Van Horne 2002). Gitman and Zutter (2012) stated that the anlaysis involves a calculation and interpretation of financial ratio, in order to analyze and monitor the financial performance of a company. Such performance could affect the stock returns from investors. An investment, according to Husnan (1998), is simply an activity to allocate funds to one or more asset for certain peroids, to gain incomes or increase its values.

Hardiningsih (2002) divided the financial performance into return on asset (ROA) and price to book value (PBV), which proved to be significant to the stock returns. Another research by Rohmah and Rina (2004) stated that the variables of economic value added (EVA), return on asset (ROA), return on equity (ROE) and return on sales (ROS) would not result a significant effect on the shareholder returns, simultaneously or partially. Furthermore, Ratnawati (2009) showed that the results for variables of debt to equtity ratio (DER) and Beta had a significance towards the stock returns, while the variables of return on equity (ROE), price to book value (PBV), and earning per share (EPS) did not affect significantly. 


\section{METHODS OF RESEARCH}

The study applies a quantitative research method, which describes a statistical fact or phenomenon and shows its connections using a mathematical model. The financial performances are measured using the variables of Debt to Equity Ratio (DER), Return On Equity (ROE), Prive Book Value (PBV), Current Ratio (CR), Total Asset Turn Over (TAT), and Price to Earning Ratio (PER). Meanwhile, the variables of macroeconomics includes inflation, exchange rate, and dummy of goverment policies to increase the availability of infrastructures. It uses the data panel regression, which combines the cross section and time series datas. Here is one example of such model:

$$
R S_{i t}=\alpha_{0}+\delta_{1} R O E_{i t}+\delta_{2} P B V_{i t}+\delta_{3} C R_{i t}+\delta_{4} P E R_{i t}+\delta_{5} D E R_{i t}+\delta_{6} T A T_{i t}+\delta_{7} I N F_{i t}+\delta_{8} \text { Kurs }_{i t}+\delta_{9} D_{i t}+e_{i t}
$$

Hypothesis: $\delta_{1} ; \delta_{2} ; \delta_{3} ; \delta_{4} ; \delta_{6}>0 \delta_{5} ; \delta_{7} ; \delta_{8} ; \delta_{9}<0$.

Where: RS = Stock Return; $\mathrm{i}=$ Company order; $\mathrm{t}=$ Times series; ROE = Return on Equity; $\mathrm{PBV}=$ Price to Book Value; $\mathrm{CR}=$ Cureent Ratio; PER = Price to Earning Ratio; DER = Debt to Equity Ratio; TAT = Total Asset Turn Over; INF = Infation Rate Kurs; Kurs = Exchange Rate; $\mathrm{D}=$ Dummy.

\section{RESULTS AND DISCUSSION}

This research applies the pooled least square. After doing a Chow test on the probability rate above 0.05 , the results of the data panel regression have underwent the criterias of normality, multicolinierity, heteroscedacity, and autocorelation tests. The estimated result shows an independent variable with a smaller probability rate than a real price of 15 percent, which are the Debt Equity Ratio (DER), Return On Equity (ROE), Price Book Value (PBV), inflation, and dummy of the Presidential Regulation No.75 of 2014. It shows the significant effect of those independent variables towards the stock returns in the construction and building subsectors.

Table 1 - The results of panel data regression

\begin{tabular}{lll}
\hline Variable & Coefficient & \\
\hline C & -0.458322 & Prob. \\
CR & -0.075445 & 0.8217 \\
DER & -0.031371 & 0.2478 \\
TAT & 0.037326 & 0.0846 \\
ROE & 1.004597 & 0.7356 \\
PBV & 0.033322 & 0.1019 \\
PER & 0.000328 & 0.0026 \\
INF & -0.049422 & 0.3952 \\
KURS & 0.090336 & 0.0003 \\
DUMMY & -0.151006 & 0.6847 \\
\hline R-squared & 0.235119 & 0.0577 \\
Adjusted R-squared & 0.187969 & \\
\hline
\end{tabular}

The Variable of Debt to Equity Ratio. The variable of Debt to Equity Ratio (DER) had a probability rate of 0.0846 , which had a significant impact on the stock returns of the construction subsector. The coefficient rate of the DER variable was about -0.0313 , meaning that if other variables were stagnant and DER had a $1 \%$ increase, then the stock return would be at $0,0313 \%$. The result was in accordance to the initial hypothesis on the negative impact of DER on the stock returns of the construction subsector. If the rate was high, there was a possibility of a low stock rate since the profit would be used to pay the debts, which decreased the stock returns from the investors. It was also in accordance to the researches by Utami (2015) and Ariyanti (2016), about the negative impact of DER towards the stock returns in the construction and building subsectors.

The Variable of Return On Equity (ROE). The probability rate on the variable of Return On Equity (ROE) was 0.1019 , which affected significantly towards the stock returns of the 
construction subsector. It showed that ROE became a reference for investors upon investing in the construction subsector. Its coefficient rate of 1.004 explained that if other variables were stagnant and ROE had a $1 \%$ increase, then the stock return would increase at $1.004 \%$. The Return On Equity showed that a capital from the owner or investor would produce a net profit. The high return of investment from investor to the company would increase its expectation towards the stock returns of the construction subsector. The higher the ratio, the higher the profit would be. It was also in accordance to the researches by Utami (2015) and Mirela (2014), which stated that ROE was a significant indicator to rate the economy and financial performances in the construction subsector.

The Variabel of Price Book Value (PBV). The variable of Price Book Value (PBV), with the probability rate of 0.0026 , had a significant effect towards the stock returns of the construction subsector. Its coefficient rate of 0.0333 showed that if other variables were stagnant and ROE had a $1 \%$ increase, then the stock return would increase at $0.033 \%$. PBV is a market ratio used to measure performances of stock market prices towards the book value. The higher the ratio, the better chance of success for stockholders to create prices. The better the prices, the more interested for the investors to invest. As the result, both the stock prices and returns would increase. It was also in accordance to the research by Akbar (2015), which stated that PBV had a positive and significant impact towards the stock returns in property and real estate sectors.

The Variable of Inflation. The variable of inflation, with the probability rate of 0.000 , had a significant effect towards the stock returns of the construction subsector. Its coefficient rate of -0.049 showed that if other variables were stagnant and ROE had a $1 \%$ increase, then the stock return would decrease at $0.049 \%$. Inflation could affect the invested price value and decrease the profits, which was in accordance with the hypothesis, as well as the research by Utami (2015), that inflation impacted negatively towards the stock returns in the construction subsector.

The Influence of the Presidential Regulation No.75 of 2014 towards the Stock Returns in the Construction Subsector. The dummy variable of the Presidential Regulation No.75 of 2014 was toincrease the availability of prioritized infrastructures, with probability rate of 0.0577 and coeffecient rate of -0.151 . The result showed that the stock return before the Presidential Regulation No.75 of 2014 was $0.151 \%$ higher than after the regulation, and was in accordance to the hypothesis about the negative impact of the regulation towards the stock return. The result also explained that one of the factors of the decreased stock prices from 2014 to 2017 was the government regulations, in particular the Presidential Regulation No.75 of 2014.

\section{MANAGERIAL IMPLICATIONS}

Companies of the construction subsector in Indonesia are obligated to the current debt for a more liquidated company and to prevent bankruptcy. They also require to decrease the DER in order to attract investors. Using the Dupont analysis, the rate of Total Asset Turn Over (TAT) was still below 1, therefore it needs to be increased for higher profitabilities.

Investors need to realize that if the DER rate is increased, the stock returns will decrease, as well as the increased rates of ROE and PBV that will increase the stock returns. Investors also need to consider that the increased inflations will decrease the stock returns for them. In addition, investors need to consider the negative effect of government policies, in particular the Presidential Regulation No.75 of 2014, towards the stock returns.

The construction and buikding subsectors has a significant role in world economics, as it contributes in infrastructures. Therefore, the government needs to stimulate the construction subsector, as well as maintaining the stability of inflation rate because the variables have a significant effect on the construction and building subsector's stock return, where the increase in inflation has resulted in an decrease in stock returns. 


\section{CONCLUSION AND SUGGESTIONS}

Through simultaneous testings, the overall independent variables (financial performances and macroeconomics) affected significantly towards the dependent variable, the stock returns in the construction subsector. The financial performances referred to the variables of Debt to Equity Ratio (DER), Return On Equity (ROE), and Price Book Value (PBV), while the macroeconomic varibles included inflation and the Presidential Regulation No.75 of 2014. Two variables significantly affected the stock returns in the construction subsector.

The relatively small coefficiency of determination $\left(R^{2}\right)$ towards the result of the data panel regression suggested that there should be other variables included in the model. The study only applied six factors of financial performances and three factors of macroeconomics, to analyze the variables affected the stock returns in the construction subsector. This should prompt future researches to focus on other factors that affect the stock returns in the construction subsector.

\section{REFERENCES}

1. Akbar R, Herianingrum S. Pengaruh Price Earning Ratio (PER), Price Book Value (PBV) and Debt to Equity Ratio (DER) Terhadap Return Saham (Studi terhadap Perusahaan Properti and Real Estate yang Listing di Indeks Saham Syariah Indonesia). JESTT. 2(9): 698-713.

2. Ariyanti S, Topowijono, Sulasmiyati S. 2016. Pengaruh Profitabilitas and Leverage terhadap Harga Saham (Studi pada Perusahaan Konstruksi and Bangunan yang Terdaftar di Bursa Efek Indonesia Periode 2011-2014). Jurnal Administrasi Bisnis. 35(2): 181-188.

3. Gitman LJ, Zutter CJ. 2012. Principles of Managerial Finance. $13^{\text {th }}$ ed. Boston (US): Prentice Hall.

4. Hampton, J J. 1990. Financial Decision Making. 4th edition. New Jersey (USA): PrenticeHall Inc, Englewood Cliffs.

5. Hardiningsih, Pancawati, Suryanto L, Chariri, Anis. 2002, Pengaruh Faktor Fundamental and Risiko Ekonomi Terhadap Return Saham Pada Perusahaan di Bursa Efek Jakarta (Studi Kasus Basic Industry \& Chemical). Jurnal Strategi Bisnis. 8:83-96.

6. Husnan, Suad. 1998. Dasar-Dasar Teori Portofolio and Analisis Sekuritas. Ed ${ }^{3}$. Jakarta (ID): UPP AMP YKYPN.

7. Kodoatie, Robert J. 2005. Pengantar Manajemen Infrastruktur. Yogyakarta (ID): Pustaka Pelajar.

8. Mirela C. 2014. Financial return in the field of constructions: what accounting issues sould an investor know?. Bulletin of the Transilvania University of Brasov. 7(56): 175-180.

9. Ratnawati R R S. 2009. Analisis pengaruh ROE, DER, PBV, EPS and Risiko Sistematik terhadap Return Saham (Studi pada Perusahaan Properti and Real Estate yang Listed Di BEI Periode (2003-2007). Jurnal Bisnis Strategi, 18(2):118-139.

10. Rohmah SN and Rina T. 2004. Pengaruh Economic Value Added and Profitabilitas Perusahaan terhadap Return Pemegang Saham Perusahaan Rokok. J. Emprika. 17(1): 64-78.

11. Utami W R, Hartoyo S, Maulana T N A. 2015. The Effect of Internal and External Factors on Stock Return: Empirical Evidence from the Indonesian Construction Subsector. Asian Journal of Business and Management. 3:370-377.

12. Van Horne, J C. 2002. Financial Management and Policy. 12nd ed. New Jersey (US): Prentice Hall.

13. Weinzimmer LG, Michel EJ, Franczak JL. (2011). Creativity and Firm-Level Performance: The Medi-ating Effects of Action Orientation. Journal of Managerial Issues. 23(1): 62-82. 